\title{
Habitat jako proces. Koncepcja środowiska zbudowanego w ujęciu dynamicznym
} Habitat as a process: The concept of the built environment from a dynamic perspective

\begin{abstract}
Streszczenie
Przedmiotem artykułu jest wstępny szkic teorii organizacji środowiska zbudowanego, będącej odpowiedzią na dynamikę procesów urbanizacji w XXI wieku. Podstawowe założenia tej teorii to: 1) temporalność i zmienność elementów habitatu, 2) nieredukowalność środowiska do jego części, 3) powiązanie różnych skal organizacji, 4) równoważenie czynników indywidualnych i kolektywnych, ciągłości i nowości, oraz uwarunkowania i wolności twórczej, 4) udział człowieka jako integralna część opisu systemu. W pracy skorzystano z wcześniejszych koncepcji strukturalistycznych, zwłaszcza teorii J. Habrakena, a także z założeń filozofii procesu A.N. Whiteheada. Rezultatem badań jest zarys procesualnego modelu organizacji środowiska, oparty o autorski zestaw pojęć technicznych, m.in. pole, zdarzenie, potencjał zdarzeń, transformacja, kontrola, wzorzec relacyjny. Elementy modelu tworzą hierarchiczny system, łączący zróżnicowane zagadnienia architektoniczne i urbanistyczne. W konkluzji przedstawiono uwagi na temat roli architekta w procesie organizacji habitatu, wynikające z przyjętych założeń teoretycznych.
\end{abstract}

\section{Summary}

The subject of the paper is a preliminary sketch of the theory of organization of the built environment, as an answer to the dynamics of urbanisation processes in the twenty-first century. The basic assumptions of this theory are: 1) the temporality and variability of habitat elements, 2) the irreducibility of the environment to its part, 3) the linking of different organisation scales, 4) balancing individual and collective factors, continuity and novelty, as well as conditioning and creative freedom; 5) human participation as an integral part of system description. The work uses earlier structuralist concepts, especially theories by J. Habraken, and also the assumptions of process philosophy by A.N. Whitehead. The result of the study is an outline of a processual model of environmental organisation, based on a original set of technical concepts, including the field, the event, event potential, transformation, control and the relational pattern. The model offers a description of the habitat as a hierarchical system synthesising various elements of architectural and urban design. This results in a new perspective of the architect's role in the organisation process of the habitat.

Słowa kluczowe: habitat, środowisko zbudowane, proces organizacji, pole, architektura Keywords: habitat, built environment, organization process, field, architecture habitat

\section{Wstęp}

Dynamika urbanizacji i rosnąca złożoność środowiska zbudowanego wymagają opracowania nowego ujęcia problemów architektury i urbanistyki (Baranowski, 2019). Współczesna teoria powinna przedstawiać projektowanie jako część szerszego procesu, co stworzy właściwą perspektywę postrzegania tej działalności w kontekście społecznym i ekologicznym. Proponuje się następujące założenia takiej teorii:

- temporalność i wewnętrzna dynamika elementów habitatu ${ }^{1}$,

- nieredukowalność środowiska do jego części,

\section{Introduction}

The dynamics of urbanisation and the growing complexity of the built environment require a new approach to the issues of architecture and urban planning (Baranowski, 2019). Contemporary theory should present architectural and urban design as part of a broader process, which creates the right perspective for this activity in social and ecological contexts. The basic assumptions of such a theory are:

- the temporality and internal dynamics of habitat elements ${ }^{1}$

- the irreducibility of the environment to its parts 
- wzajemne powiązanie różnych skal organizacji,

- równoważenie czynników indywidualnych i kolektywnych, ciągłości i nowości oraz wolności i uwarunkowania.

Przedstawiona koncepcja wpisuje się w paradygmat strukturalistyczny tzn. jest poszukiwaniem głębokiego podłoża obserwowalnej rzeczywistości - uniwersalnej struktury wyjaśniającej różnorodność jednostkowych przejawów. Praca dotyczy habitatu per se, nie zaś jego konkretnych realizacji w określonych kontekstach historyczno-geograficznych. Struktura rozumiana jest dynamicznie - jako system przekształceń (Piaget, 1972, s. 37-40). Ujawnienie struktury prowadzi do zrozumienia natury procesu organizacji.

Jedną z dotychczasowych teorii środowiska zbudowanego opartych na strukturalizmie ${ }^{2}$ jest koncepcja Johna Habrakena przedstawiona w dziele "Structure of the Ordinary". Środowisko w modelu Habrakena tworzy całość uporządkowaną według hierarchii poziomów organizacji ${ }^{3}$. Model hierarchiczny pozwala na powiązanie elementów habitatu o różnych skalach przestrzennych i analizę problemów formy, terytorialności, oraz kontroli. W niniejszej pracy kontynuuje się tę metodę, przyjmując za cel powiązanie wymienionych aspektów w jednym procesie organizacji przestrzeni.

Inspiracją dla podjęcia tematu była filozofia procesu angielskiego matematyka i filozofa Alfreda Northa Whiteheada wyłożona w dziele "Process and Reality" z roku 1929. U podstaw systemu Whiteheada leży przekonanie o dynamicznej naturze istnienia. To co rzeczywiste (aktualne) jest równocześnie temporalne, a to co absolutnie trwałe jest abstrakcyjne. Świat staje się - od najprostszych zaistnień na poziomie kwantów, po akty świadomości człowieka. Za naczelną zasadę metafizyczną Whitehead uznawał kreatywność (Whitehead, 1978, s. 21-22). Proces stawania się każdego zaistnienia uwarunkowany jest innymi zaistnieniami, co jednak nie określa jego ostatecznej postaci, ponieważ każde zaistnienie konstytuuje się dokonując wolnego wyboru z dostępnych możliwości (Cobb, 2016, s.133-139). Uderzające jest podobieństwo tej wizji do codziennego doświadczenia habitatu, w którym proste decyzje współtworzą złożone całości a kontynuacja towarzyszy nieustannej zmianie.

Celem niniejszego artykułu jest przedstawienie procesualnego modelu środowiska zbudowanego. Praca nie neguje indywidualnej specyfiki architektury, urbanistyki, wzornictwa etc. Zakłada się jednak, że organizacja środowiska oznacza więcej niż zwykłą sumę tych dyscyplin. Podkreśla się raczej ciągłość pomiędzy różnymi skalami organizacji, niż ich odrębność.

Chociaż praca dotyczy środowiska codziennego, język techniczny opisu może wydawać się nieprzejrzysty. Zachodzi jednak potrzeba wprowadzenia terminów obejmujących rzeczy lub działania, których nie łączymy ze sobą w codziennej praktyce. I tak na przykład, pojęcie transformacji odnosi się skali urbanistycznej jak i skali przedmiotów codziennego użytku np. do założenia miasta i do urządzenia pokoju. Dla uniknięcia niejasności, do opisów pojęć dołączono przykłady ich zastosowania 4 .

\section{Model organizacji środowiska \\ 2.1. Opis podstawowy}

i. Elementarną jednostką procesu organizacji środowiska jest pole.
- the interrelationship of different scales of space organisation

- the environment as a synergy of: individual and collective factors, continuity and novelty, as well as creative freedom and limitation.

The presented concept is part of the structuralist paradigm, i.e. it is a search for a deep foundation of observable reality-a universal structure explaining the diversity of individual phenomena. The work concerns the built environment per se, and not its variations in specific historical and geographical contexts. The structure is understood dynamically-as a system of transformations (Piaget, 1972, pp. 37-40). Revealing the structure of the environment leads to an understanding of the nature of the process of its organisation.

One of the fullest contemporary theories of the built environment based on a structural approach ${ }^{2}$ is the concept of John Habraken presented in Structure of the Ordinary. The environment in Habraken's concept creates a whole ordered according to the hierarchy of organisation levels. ${ }^{3}$ The hierarchical model allows for linking different spatial scales and for analysing problems of form, territoriality and control. In the present work, the method is continued, with the goal of producing a synthesis of these aspects in a single process of space organisation.

The inspiration for current work was the process philosophy of Alfred North Whitehead, presented in Process and Reality in 1929. At the base of Whitehead's system is the belief in the dynamic nature of existence. What is real (actual) is simultaneously temporal, and what is absolutely permanent is abstract. According to Whitehead, the world is constantly becoming - from the simplest entities at the quantum level to the acts of human consciousness. The ultimate metaphysical principle of actual existence for Whitehead is creativity (Whitehead, 1978, pp. 21-22). The process of becoming of each entity is conditioned by other entities which nevertheless do not ultimately determine its outcome. Each entity is constituted by making a free choice from the available options (Cobb, 2016, pp. 133-139). This vision bears striking resemblance to the everyday experience of the habitat, in which simple decisions co-create complex wholes and continuation is followed by change.

The aim of this paper is to present the processual model of the built environment. This does not negate the individuality of urban planning, architecture, interior design etc. However, it is assumed that environmental organisation means more than just the sum of these disciplines. Therefore, the continuity between different scales of the organisation is emphasised.

Although this work deals with the everyday environment, the technical language of the description may at first seem unclear. It resulted from the need to introduce common terms for things that we do not combine in everyday practice. For example, the concept of transformation may refer to both the foundation of a city and the arrangement of an interior. To avoid confusion, descriptions of concepts are accompanied by examples of their use. 
ii. Pole jest obszarem wyodrębnionym za pomocą przedmiotów fizycznych, który jest areną zdarzeń przestrzennych.

iii. Pole posiada określony potencjał zdarzeń określony sumą:

- układu przedmiotów wyodrębniających pole,

- kontroli pola.

vi. Elementami konfiguracji pola są: infrastruktura, przestrzeń obsługowa, oraz pola lokalne.

v. Kontrola ma na celu utrzymanie określonego potencjału zdarzeń w polu.

vi. Zdarzenia to obecność fizyczna ludzi i przedmiotów.

vii. Transformacja to zmiana konfiguracji przedmiotów w polu prowadząca do zmiany układu pól lokalnych.

viii. Celem transformacji jest aktualizacja potencjału zdarzeń pola.

ix. Danymi wyjściowymi dla transformacji jest potencjał zdarzeń pola oraz aktualna konfiguracja zdarzeń w polu.

x. W procesie transformacji dokonywany jest wybór wzorca relacyjnego, który jest abstrakcyjnym obrazem stanu pola.

\subsection{Pole i zdarzenie}

Zwykła obserwacja miast, budynków, pomieszczeń etc. wskazuje na paradoks: środowisko nieustannie podlega zmianie, a równocześnie zachowuje stabilność.

Ulica pozostaje 'tą samą' ulicą, mimo że z upływem czasu jej pierwotna zabudowa zostaje wymieniona. Pokój pozostaje 'tym samym' pokojem, mimo że z biegiem lat zmienia się całkowicie jego wystrój.

Ani trwałość, ani zmienność nie może zostać wyłączona z opisu środowiska. Opis statyczny nie wyjaśnia działania systemu, podczas gdy uznanie, że 'wszystko płynie' prowadzi do wniosku, że kategorie opisowe (pokój, dom, miasto etc.) opierają się na złudzeniu.

Trwałość w środowisku jest realna, podobnie jak zmienność. Jednak obie kategorie mają sens wyłącznie w odniesieniu do siebie samych - nie są zatem absolutne, ale relatywne. $\mathrm{W}$ przedstawionym modelu trwałość reprezentowana jest jako pole a zmienność jako zdarzenie. Pole oznacza wydzieloną całość przestrzenną, w której pojawiają się ludzie i przedmioty fizyczne, przy czym ich obecność jest epizodyczna. Ludzie przemieszczają się

\section{The model of environmental organisation}

2.1. Basic description

i. The field is the elementary unit of the organisation process .

ii. The field is a region defined by physical objects-the arena of spatial events.

iii. The field has a specific event potential described by the sum of:

- the arrangement of objects defining the field

- field control.

iv. Elements of the field configuration are: infrastructure, service space, and local fields.

v. The control aims to maintain a specific event potential in the field.

vi. Events mean the physical presence of people and objects.

vii. A transformation is a change in the configuration of objects in a field that leads to a change in the layout of local fields.

viii. The purpose of the transformation is to fulfil the field event potential.

ix. The initial data for the transformation is the field event potential and the current field event configuration.

$\mathrm{x}$. In the transformation process, a relational pattern is selected, which is an abstract image of the state of the field.

\subsection{Field and event}

Simple observation of cities, buildings, rooms etc. points to two facts: the environment is constantly changing and, at the same time, maintains stability.

The street remains 'the same' street, despite the fact that its original buildings are replaced over time. The room remains, in a sense, 'the same' room, although its decor may be changed completely.

Neither stability nor variability can be excluded from the description of cities and buildings. A 'frozen' morphological image does not explain operation of the system. However, environmental change is not simply continuous. To acknowledge that 'everything flows' would mean that our descriptive categories

II. 1. Podstawowe elementy modelu. (opr. własne) / Basic elements of the model (author's drawing)

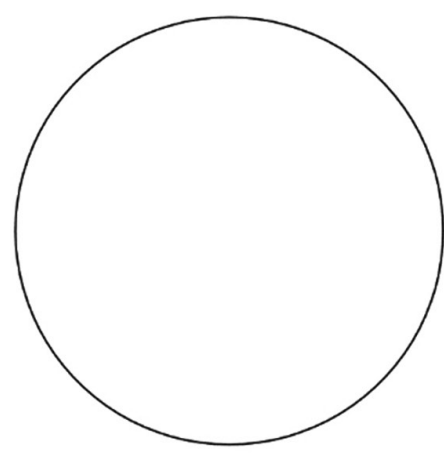

field

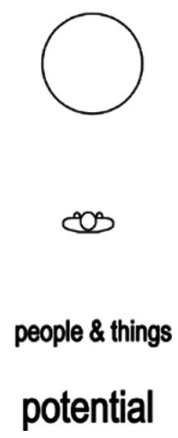

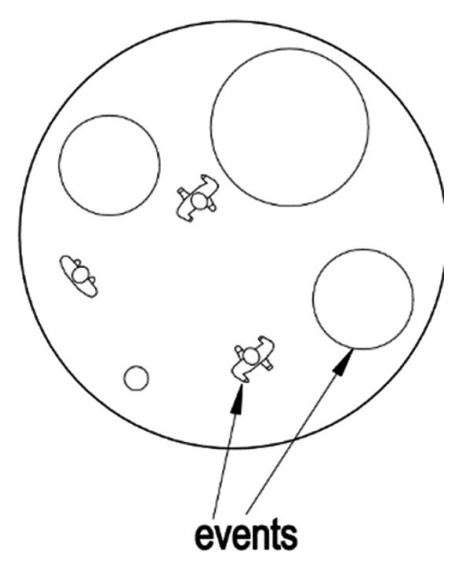




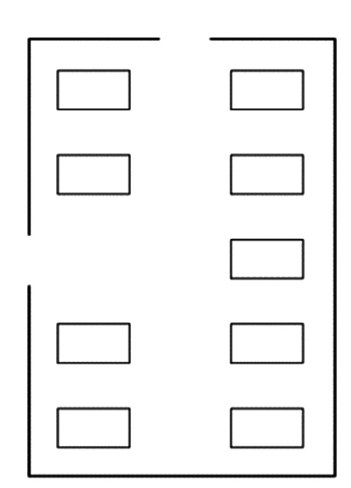

a

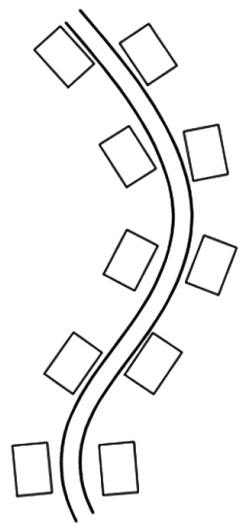

$25 \mathrm{~m}$

b

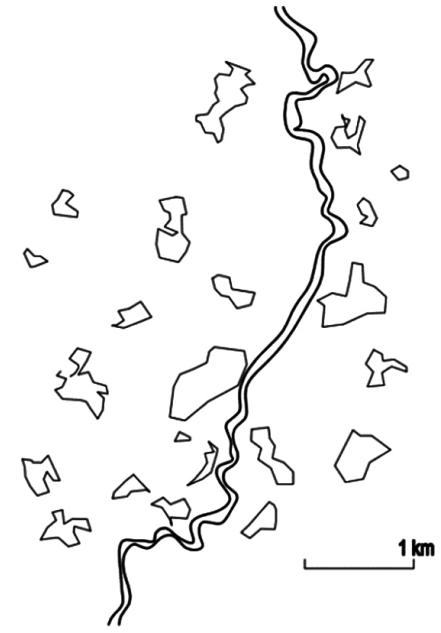

b

II. 2. Przykłady pól i zdarzeń (opr. własne) / Examples of fields and events (author's drawing)

w obrębie pola lub opuszczają je, przedmioty zaś podlegają transformacji. Są zatem zdarzeniami w polu, które samo ma charakter stały ${ }^{5}$ (II. 1).

Stoliki w restauracji (a), domy przy ulicy (b), wsie w dolinie (c) to przykłady zdarzeń w określonych polach (II. 2). Status pola i zdarzenia elementów układu zależy od poziomu analizy. Środowisko jest zorganizowane w oparciu o hierarchię zagnieżdżoną tj. zawieranie się elementów z niższych poziomów w elementach z poziomu wyższego. Zdarzenie w polu wyższego poziomu może tworzyć pole na niższym poziomie (pole lokalne), które samo zawiera zdarzenia (II. 3).

Stoliki są zdarzeniami w polu 'restauracja'. Stolik jest polem, w obrębie którego zachodzą kolejne zdarzenia pojawiają się ludzie (klienci, obsługa) i przedmioty (krzesła, zastawa etc.) (room, house, city, etc.) are based on an illusion of permanence and are not real.

Environmental stability is real, and so is variability. However, both categories make sense only in their mutual relation-they are therefore not absolute but relative. In the presented model, persistence is represented by the category of the field, and variability-by events. The field means a separate spatial unity in which people and physical objects appear, with their presence in the field being episodic. People move around or leave the field, and objects undergo transformation. Therefore, they are events in the field that is permanent in itself. ${ }^{4}$ (il. 1)

Tables in a restaurant (il. 2a), houses on a street (il. 2b), villages in a valley (il. 2c) are examples of events in specific fields.

II. 3. Hierarchia pól $F_{1}, F_{2}, F_{3} \ldots F_{n}$ (opr. własne) / Hierarchy of fields (author's drawing)

II. 4. Struktura pola: F- pole zawierające, f- pole zawierane, C-rdzeń, T-przestrzeń progowa, S-przestrzeń obsługowa (opr. własne) III. 4. Field structure: $F$ - including field, $f$-local field, $C$ - core, $T$ - threshold space, $S$ - servicing space (author's drawing)
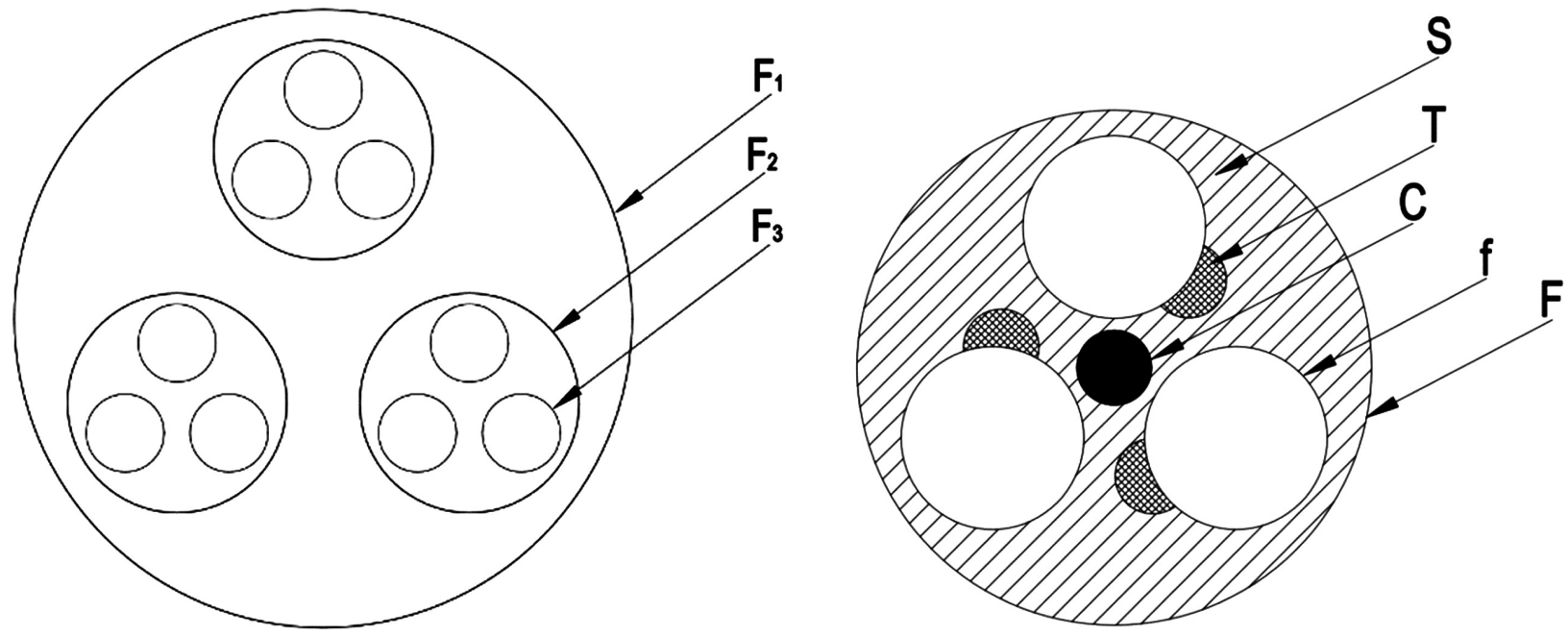


\subsection{Potencjał zdarzeń}

Organizacja środowiska jest procesem celowym, zorientowanym na rozwój życia społecznego we wszystkich jego przejawach. Przekształcenia środowiska mają na celu stworzenie możliwości urzeczywistnienia określonych zdarzeń, przy czym potencjał ten może mieć różny stopień ogólności ${ }^{6}$.

Skutkiem sukcesywnych transformacji pola, prowadzących do powstania coraz bardziej ograniczonych pól lokalnych, są coraz bardziej zawężone potencjały zdarzeń. Proces ten prowadzi ostatecznie do zupełnego urzeczywistnienia (aktualizacji) zdarzeń.

Rozważmy np. lokację miasta średniowiecznego. Wytyczenie rynku, dróg i parceli, budowa murów etc. to transformacja stwarzająca szerokie spektrum możliwości obejmujące całe bogactwo życia gospodarczego i kulturalnego, religijnego etc. Nie są to jednak docelowe zdarzenia, ale jedynie ich potencjał. Budowa domu przez obywatela miasta to transformacja dookreślająca potencjał zdarzeń, który jest węższy i wyraźniej zarysowany. Urządzenie w tym domu warsztatu a w nim stołu, przy którym rzemieślnik mógt wytwarzać swoje wyroby, to kolejne transformacje tego rodzaju. Bez tych sukcesywnych zawężeń ostateczne zdarzenie, w tym wypadku była praca i utrzymanie się konkretnego człowieka, nie byłoby możliwe.

Dychotomia pola i zdarzenia ujmuje zatem nie tylko równowagę pomiędzy trwałością i zmianą, ale również pomiędzy potencjałem i jego aktualizacją.

\subsection{Struktura pola}

Pole stanowi podstawową jednostkę organizacji środowiska, co oznacza, że jest najprostszą możliwą formą uporządkowania, związaną z pewnym identyfikowalnym obszarem. W obrębie pola można wyróżnić dwie podstawowe kategorie przestrzeni:

1) przestrzeń ogólną pola

2) pola lokalne
Field and event status is not assigned to an arrangement of objects in an absolute way, but depends on the level of analysis. The environment is organised based on a nested hierarchy: an event in a higher-level field can create a lower-level field (local field) which contains events in itself (il. 3 ).

The tables are events in the 'restaurant' field. The table is also a field within which subsequent events occurappearing people (clients, staff) and objects (chairs, tableware etc.).

\subsection{The potential of events}

The organisation of the environment is a purposeful process, oriented towards the development of social life in all its manifestations. Each transformation of the environment aims to create the possibility for certain events to occur. This potential can have a different degree of generality. ${ }^{5}$

The effect of successive field transformations, leading to the emergence of increasingly limited local fields, are more and more narrowed event potentials. This process ultimately leads to the complete realisation (actualisation) of events.

Let us consider the process of the founding of a medieval city. Delineating the market, roads and parcels etc. is a transformation of space which has resulted in a wide spectrum of possibilities covering all the wealth of economic, cultural, religious etc., life. However, it was only an anticipation of the future-the potential for events, not the events themselves. The construction of a house by a citizen defined a field in which the potential for events was much narrower, and more clearly outlined. The establishment of a workshop in this house, and in it a table at which a craftsman could manufacture their products, are further transformations of that type. Without this successive narrowing,

II. 5. a) rzut typowego podmiejskiego domu parterowego b) interpretacja tego samego domu w kategoriach modelu: $F$ - pole zawierające, $f-$ pole lokalne, S - przestrzeń obsługowa (opr. własne)

III. 5. a) Plan of a typical suburban single-storey house b) the interpretation of the same house using the model: $F-$ including field, $f-$ local field, S - servicing space (author's drawing)

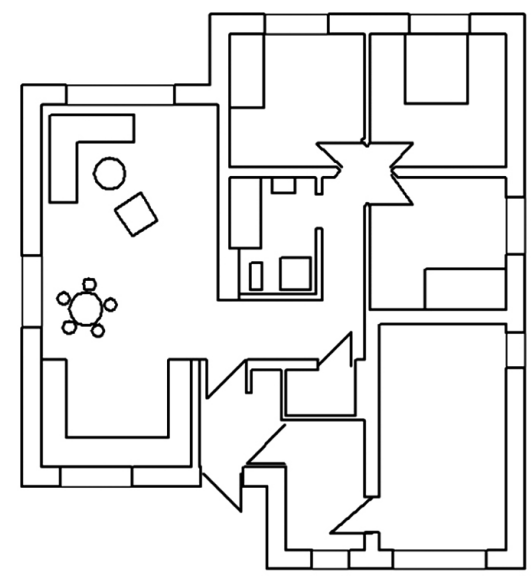

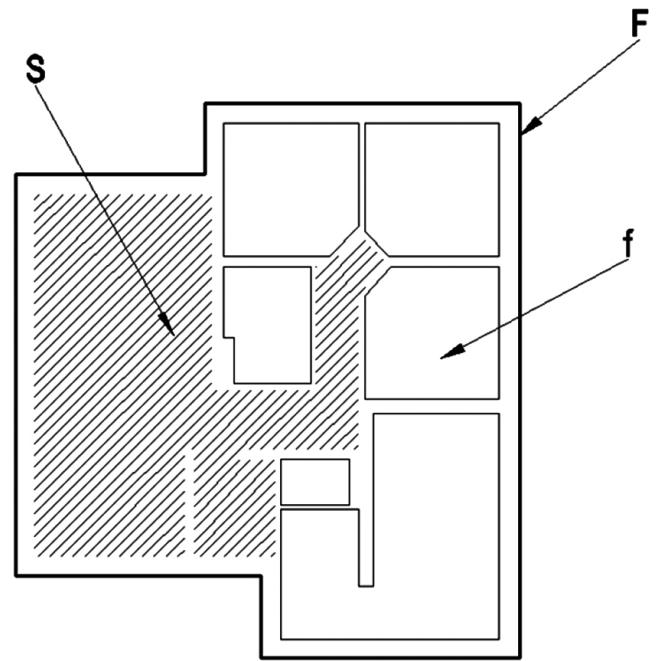

b 
Przestrzeń, która pozostaje po wydzieleniu pól lokalnych z przestrzeni ogólnej ma charakter pomocniczy względem tych pól: jest przestrzenią obsługową, a pola lokalne - przestrzenią obsługiwaną. Funkcją przestrzeni obsługowej jest tworzyć relacje pomiędzy polami lokalnymi, zwłaszcza zapewnić cyrkulację ludzi i możliwość ich interakcji. Podstawowymi elementami tej przestrzeni są ścieżki, rdzenie i przestrzenie progowe7(II. 4).

Współczesny dom jednorodzinny jest polem, które zawiera w sobie szereg pól lokalnych w postaci zamykanych pomieszczeń, np. sypialni. Do przestrzeni obsługowej należą korytarze, schody etc. pełniące funkcję ścieżek, ale również otwarty salon, pełniący funkcję rdzenia (integracja mieszkańców) (II. 5).

Pole wyznaczone jest układem przedmiotów fizycznych, które umożliwiają funkcjonowanie pola zgodnie z jego potencjałem - możemy nazwać je infrastrukturą pola, lub - za Habrakenem - 'podporą' (support) (Habraken, 1966, s. 138).

Infrastrukturą pokoju są ściany, podłoga, strop, okna, drzwi, instalacje etc. Infrastrukturą działki budowlanej są elementy wyznaczające granicę własności, przyłącza sieciowe etc. Infrastrukturą osiedla są jezdnie, chodniki, oświetlenie, sieci techniczne etc.

Infrastruktura może być sytuowana centralnie względem pól lokalnych (jak w przypadku drogi i domów przy drodze) albo zawierać pola lokalne (jak w przypadku pomieszczenia i jego wyposażenia). Pojęcie pola wydaje się usuwać tradycyjną sprzeczność pomiędzy przestrzenią pozytywową i negatywową ${ }^{8}$. Te dwa rodzaje przestrzeni nie są rozłącznymi kategoriami, ale raczej dwoma bliźniaczymi aspektami pola: jego odziaływaniem dośrodkowym i odśrodkowym - a więc wpływem pola, jaki rozciąga się na wnętrze tego pola i na jego obrzeże. Stół działa jako soliter, wokół którego ustawiane są krzesła i siadają ludzie, oraz jako przestrzeń wewnętrzna (blat stołu), na którym układa się nakrycia itp. Także budynek - w oczywisty sposób określa przestrzeń wewnętrzną, ale również emanuje na zewnątrz tworząc pewną strefę użytkową wokół siebie (II. 6).

\subsection{Kontrola i transformacje}

Proces organizacji podtrzymywany jest przez ludzką kreatywność i wolę, co objawia się w transformacjach i kontroli. Celem kontroli jest utrzymanie pewnych własności the final event, which in this case was the work and maintenance of a specific person, would not have been possible.

Therefore, the dichotomy of the field and the event captures not only the balance between persistence and change but also between potential and its actualisation.

\subsection{Field structure}

The field is the basic unit of environmental organisation, which means that it is the simplest possible form of ordering associated with some identifiable area.

Within the field, two basic categories of space can be distinguished:

1) the general space of the field

2) local fields.

Local fields are separated from the general space of the field due to narrowed event potential. The rest of the general space is auxiliary. Local fields are the serviced space, while the remaining part is the servicing space. The function of the servicing space is primarily to create relationships between local fields, especially to ensure the circulation of people among them and to integrate users assigned to individual fields. Therefore, the basic elements of that space are paths, cores and threshold spaces. ${ }^{6}$ (il. 4)

A contemporary single-family house is a field that contains a number of local fields in the form of enclosed spaces, e.g. individual rooms. The general space includes corridors, stairs, etc. fulfilling the function of paths, but also an open living room, serving as the core (integration of residents) (il. 5).

Physical objects enable the field to function according to its event potential—we can call it a field infrastructure or, according to Habraken's terminology, 'a support' (Habraken, 1966, p. 138).

The infrastructure of the room are walls, floor, ceiling, windows, doors, installations etc. The infrastructure of a construction plot consists of the elements that determine the limit of ownership, utility service connections etc. The estate's infrastructure are roadways, pavements, lighting, technical networks, etc.

The infrastructure can be located centrally in relation to local fields (as in the case of roads and houses
II. 6. Przykład pola o podwójnej (wewnętrznej i zewnętrznej) konfiguracji (opr. własne)

III. 6. Example of a field with a double (internal and external) configuration (author's drawing)

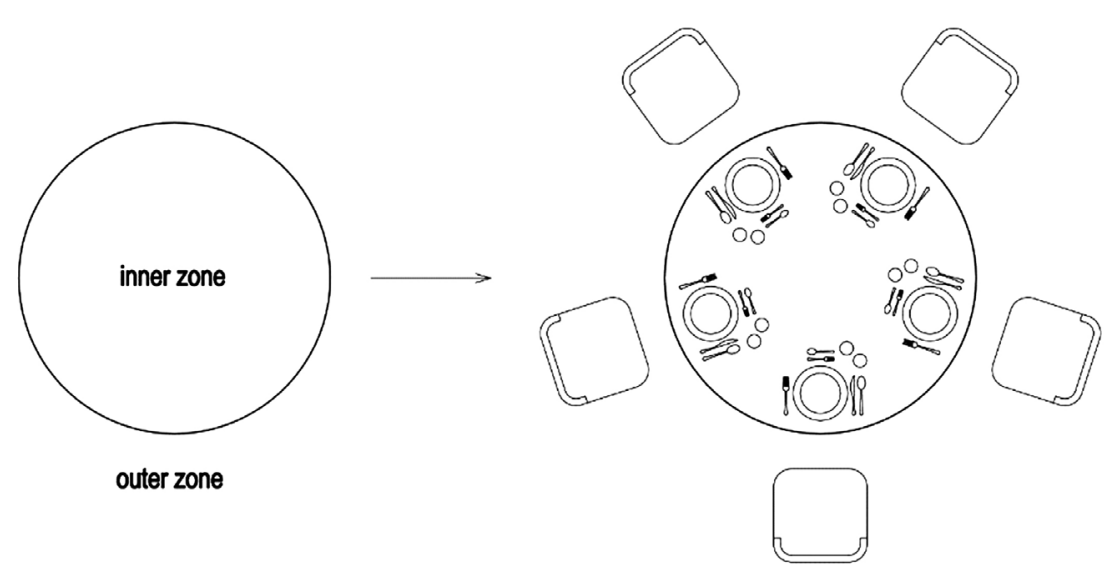


pola. Kontrola dostarcza transformacji danych inicjalnych. Urbanista ograniczający dopuszczalną wysokość zabudowy na danym terenie dokonuje aktu kontroli poszczególnych budynków. Wspólnota sąsiedzka w budynku wielorodzinnym kontroluje dostęp dla osób niebędących mieszkańcami.

Kontrola jest skomplikowanym zjawiskiem sumującym wiele elementów: formalne i nieformalne normy społeczne, indywidualne preferencje podmiotów sprawujących kontrolę, specyfikę funkcji, jakiej służyć ma dane pole etc. W ramach kontroli podmiot może użyczyć część własnych praw innemu podmiotowi, albo ograniczać prawa indywidualne.

Właściciel galerii handlowej użycza najemcom lokali usługowych prawa do wyposażenia ich według swoich upodobań i prowadzenia działalności w określonym zakresie. Inwestor może zabudować działke obiektem o funkcji i gabarytach dopuszczonych przez miejscowy plan zagospodarowania przestrzennego.

Transformacja jest przekształceniem pola mającym na celu aktualizację potencjału zdarzeń. Przebieg transformacji można opisać następującymi etapami:

ustalenie celu > przyswojenie danych wyjściowych > wybór wzorca relacyjnego $>>$ realizacja.

Na dane wyjściowe składają się następujące elementy:

- ukształtowanie fizyczne pola,

- zdarzenia trwające uprzednio w polu,

- kontrola pola.

Dane te są 'przyswojone' w ten sposób, że ograniczają kreację. W tym sensie i do tego stopnia każda transformacja zdeterminowana jest przez swoje otoczenie.

Następnie transformacja przechodzi w fazę spekulacji. Badane są możliwości realizacji celu w zadanych warunkach, czyli wzorce relacyjne. Wzorzec może występować jako idea, koncepcja, wyobrażenie, schemat, plan, obraz, projekt etc. Jest symboliczną reprezentacją pola i zdarzeń po dokonaniu transformacji. Jego treścią są relacje pomiędzy częściami i całością wyobrażonego układu. Wzorzec w odróżnieniu od pola i zdarzenia jest absolutnie statyczny i wyabstrahowany z kontekstu9 .

Decyzja o wyborze wzorca jest aktem kreacji. Realizacja wzorca jest jego aktualizacją - wprowadzeniem w czas i przestrzeń.

Dane jest pewne pole: peron na stacji kolejowej. Jego potencjał zdarzeń obejmuje m.in. innymi oczekiwanie pasażerów na pociąg. Celem transformacji jest konkretyzacja tego potencjału - umożliwienie oczekiwania w pozycji siedzącej. Ustawienie tawek wymaga: uwzględnienia odpowiedniej odległości od krawędzi peronu (ukształtowanie pola), usytuowania istniejących elementów w polu - rozkładów jazdy, automatów biletowych etc. (zdarzenia uprzednie). Możliwe, że wybór tawki (jej wzór, kolorystyka etc.) będzie podyktowany ogólną koncepcją plastyczną elementów wystroju dworca (kontrola pola). Uwzględniwszy te dane wyjściowe należy rozpatrzyć możliwości rozmieszczenia ławek, które usytuowane podłużnie lub poprzecznie, jedna za drugą lub zwrócone ku sobie, zgrupowane lub nie, etc. (wzorce relacyjne). W dalszej kolejności następuje wybór wariantu i jego realizacja. Pasażerowie mogą już siadać na ławkach, stawiać na nich bagaże etc. (nowe pola i potencjały zdarzeń). along the road), or include local fields (as in the case of a room and its furnishings).

This way, the concept of the field seems to remove the traditional contradiction between positive and negative spaces. ${ }^{7}$ These two types of space are two twin aspects of the field: its centripetal and centrifugal interactions-i.e. the influence of the field that extends inside the field and to its periphery.

The table works as a solitaire, around which chairs are placed, people sit down, and as an internal space (table top), on which covers are laid, etc. The same way, the building clearly defines an internal space, but also influences the outside, creating a certain usable area around it (il. 6).

\subsection{Control and transformation}

The organisation of the habitat is a process constantly supported by human creativity and will that manifest through transformations and control. Control is an external category to transformation and provides initial data for it. Transformation is used to create or change specific events within a field, while the purpose of control is to maintain certain qualities of the field.

An urban planner limiting the permissible building height in a given area performs an act of control of individual buildings. The neighbourhood community controls access of non-residents to a given multi-family building.

Control is a complicated phenomenon that is the sum of formal and informal social norms, individual preferences of the entities exercising control, the character of the function the field is to serve, etc. As part of the control, the given actor may grant some of their own rights to another actor, or limit individual rights.

The owner of a shopping mall allots to the tenants the right to furnish individual premises according to their preferences and conduct business in a certain scope. The developer may develop a plot of land with a building with functions and dimensions allowed by the local spatial development plan.

Transformation is a modification of the field aimed at updating the potential of events. It can be described in the following stages:

goal setting $>$ the assimilation of initial data $>$ the selection of relational pattern $>>$ implementation

The initial data consist of the following elements:

- physical topography of the field

- events occurring previously in the field

- field control.

These data are 'assimilated' in a certain way, limiting the creation. In that sense and to that extent, every transformation is determined by its surroundings.

Later, the transformation enters the phase of thought speculation. The possibilities of achieving a goal in the given conditions are examined-relational patterns. A pattern can appear as an idea, a concept, an image, a diagram, a plan, a picture, a project etc. It is a symbolic representation of the field and events after transformation. Its content is the relationship between the 

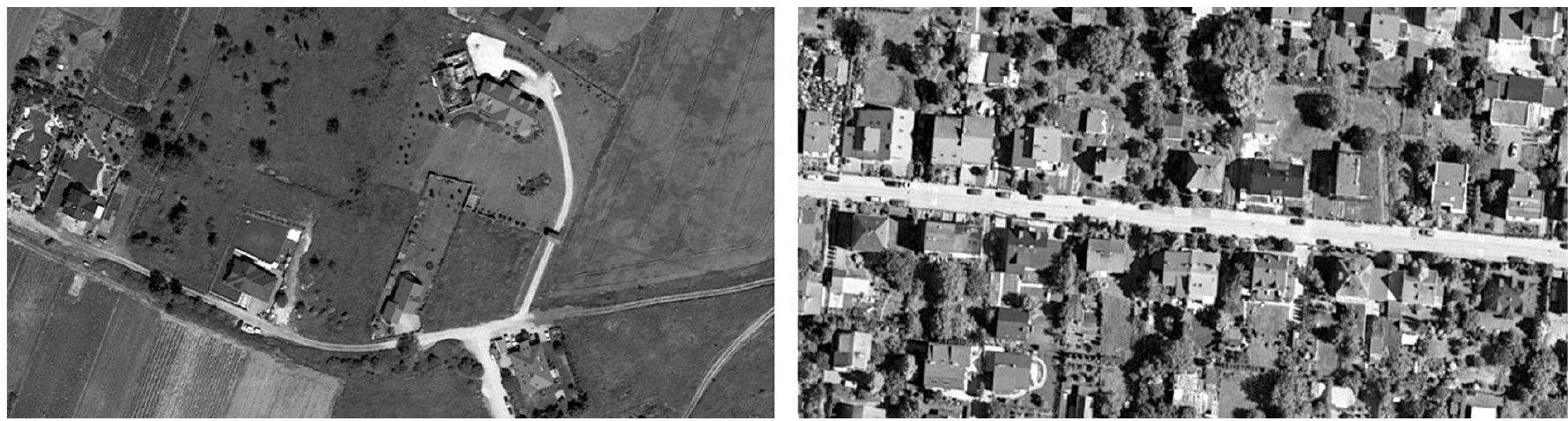

II. 7. Po lewej: stopniowa parcelacja terenów rolniczych pod cele mieszkalne. Po prawej: regularna zabudowa ulicy w wyniku skoordynowanej parcelacji większego obszaru (Google)

III. 7. On the left: gradual division of agricultural land for residential purpose. On the right: regular development of the street as a result of a coordinated division of a larger area (Google)

\subsection{Rodzaje transformacji}

Wynikiem transformacji może być stworzenie jednego pola lokalnego (transformacje pojedyncze) lub więcej takich pól (transformacje złożone). Możliwe są konfiguracje składające się z wielu pól lokalnych, które powstają w wyniku sukcesywnych pojedynczych transformacji lub w wyniku jednej złożonej transformacji.

Zabudowa domów przy wiejskiej drodze może powstawać stopniowo - poprzez wykrajanie kolejnych parceli budowlanych albo poprzez jedną skoordynowaną parcelację. (II. 7)

Powyższe przykłady dotyczą transformacji, w wyniku których powstające pola są symetryczne, tzn. nie zawierające siebie nawzajem. W organizacji środowiska występuje często zjawisko transformacji wielopoziomowej, w wyniku której powstają hierarchie pól. Podczas jednego skoordynowanego działania tworzone są pola, w których 'od razu' zawierają się inne pola. 'Klasyczny' proces jest w tym przypadku skrócony i uproszczony: za kilka poziomów organizacji odpowiada jeden podmiot dokonujący transformacji.

Budowa współczesnego budynku mieszkalnego jest transformacją wielopoziomową. W obrębie dziatki (pole poziomu n) sytuuje się budynek (pole poziomu $n+1)$, w którym znajdują się lokale mieszkalne lpola poziomu $n+2)$ a w nich - z reguty - wydzielone pomieszczenia (pola poziomu $n+3$ ).

\subsection{Samoorganizacja pola}

Szczególnym rodzajem procesu jest samoorganizacja, czyli powstanie struktury wyższego rzędu poprzez interakcje elementów niższego rzędu (tzw. zjawisko emergentne). Samoorganizacja jest procesem oddolnym: pole globalne nie istnieje uprzednio w całości, ale ‘wyłania się' wraz z poszczególnymi polami lokalnymi.

Samoorganizacja nie zaprzecza zasadzie epizodyczności zdarzeń i trwałości pola, ponieważ trwanie pola obejmuje wszystkie transformacje, chociaż wraz z transformacjami zmienia się jego kształt. (II. 8)

Przykładem samoorganizacji jest 'samorzutna' urbanizacja. Bill Hillier opisał proces oparty na prostych regułach grupowania pojedynczych budynków i towarzyszących im przestrzeni otwartych (Hillier, 1984, s. 52-62). Wraz budową kolejnych domów powstają kolejne odcinki ulic ${ }^{10}$. (II. 9) parts and the whole of the imaginary system. The pattern, unlike the field and the event, is absolutely static and abstracted from the context. ${ }^{8}$

The decision to choose a pattern is an act of creation. The implementation of the pattern is its actualisationan introduction to time and space.

There is a certain field: a platform at a railway station. Its event potential includes, among others, the act of waiting when passengers wait for a train. The purpose of the transformation is to concretise that potential: to enable the waiting in a sitting position. The arrangement of benches requires: taking into account the appropriate distance from the edge of the platform (shape of the field), the location of existing elements in the field-timetables, ticket vending machines, etc. (previous events). It is possible that the choice of the bench (its design, colour, etc.) will be dictated by some general artistic concept of the station's design elements (field control). Considering all these input data, various options for the location of benches should be considered-they can be located longitudinally or transversely, stand one behind the other, or facing each other, be grouped or 'scattered' throughout the platform, etc. (relational patterns). Next, an alternative is selected and implemented. Passengers can now sit on the benches, put luggage on them etc. (new fields and event potentials).

\subsection{The types of transformation}

The result of the transformation may be the creation of one local field (single transformations) or more of such fields (complex transformations). Large configurations may arise as a result of successive individual transformations or as a result of one complex transformation (or a mixture of both).

Buildings along the country road can be built up gradually-by cutting out subsequent building plots from existing fields or through one coordinated plot division (il.7).

The above examples relate to transformations that result in symmetrical local fields, i.e. not containing each other. However, there are often multi-level transformations, which result in the creation of field hierarchies. 

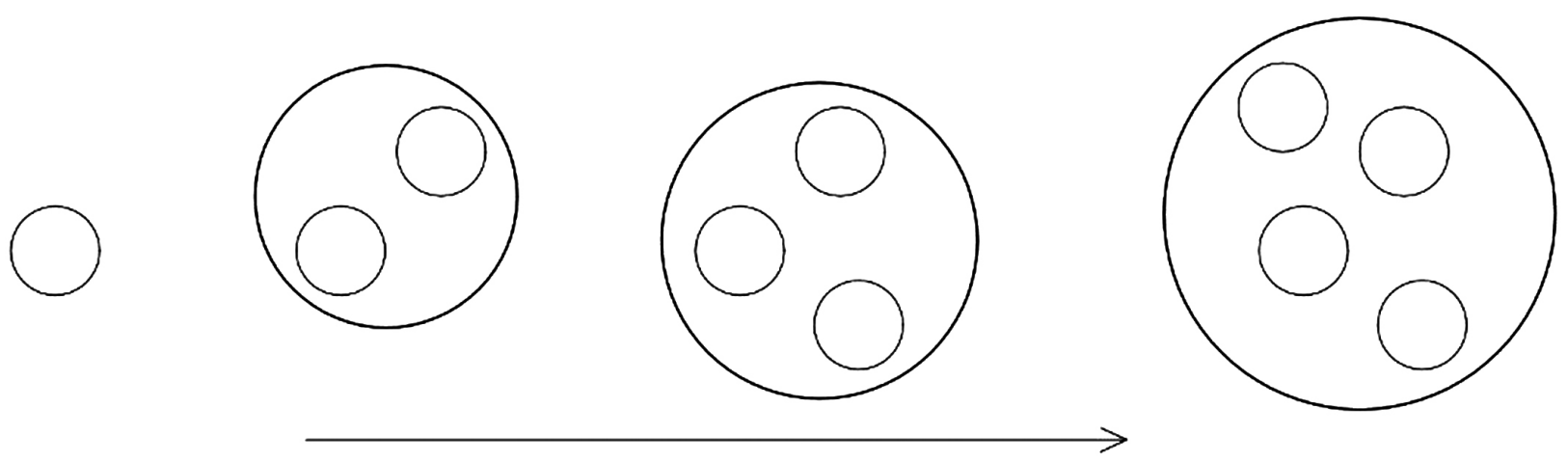

II. 8. Ideogram samoorganizacji (opr. własne) / Ideogram of self-organisation (author's drawing)
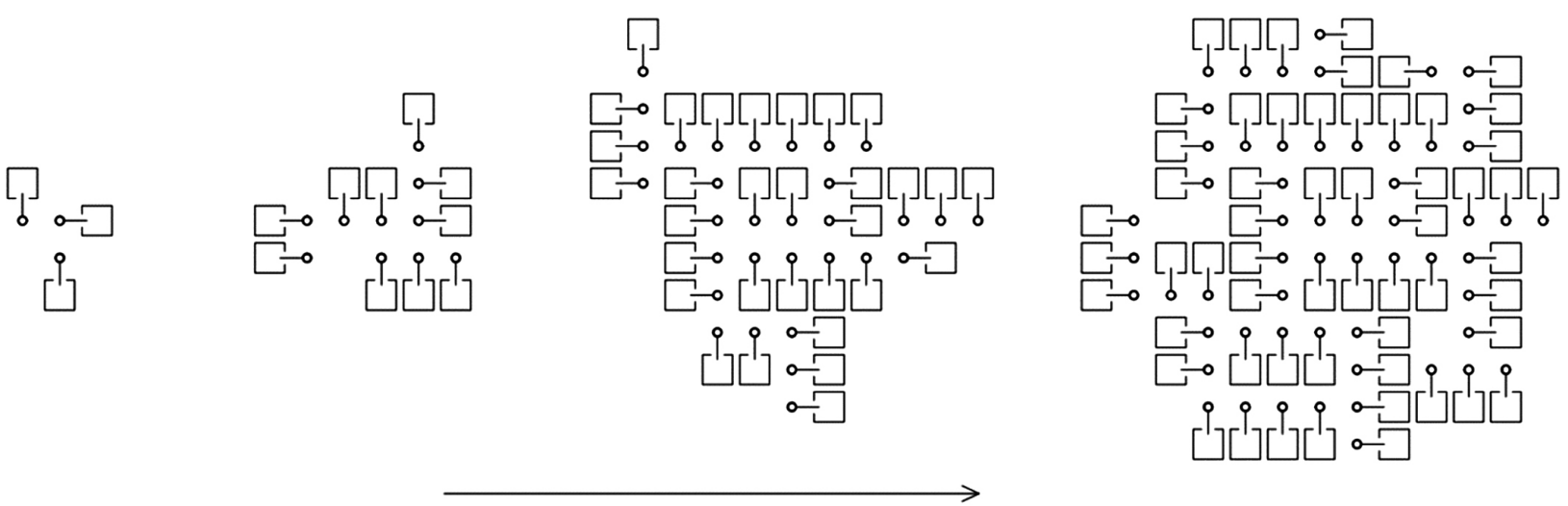

II. 9. Rozwój zespołu zabudowy opracowany wg algorytmu B. Hiliera i P. Coatsa (opr. własne)

III. 9. Development of an urban unit devised according to the algorithm of B. Hillier and P. Coats (author's drawing)

\subsection{Człowiek w środowisku}

W tradycyjnym ujęciu środowisko przedstawiane jest jako obiekt, który istnieje niezależnie od człowieka i jest, niejako wtórnie, przez człowieka doświadczany ${ }^{11}$. Jednak człowiek nie jest wyłącznie odbiorcą środowiska (ani nawet odbiorcą i twórcą zarazem), ale jego integralną części (Hillier, 1984, s.3-9).

Środowisko zbudowane składa się z ludzi i przedmiotów fizycznych. Obie kategorie stanowią obserwowalne fakty i obie zaliczają się do szerszej kategorii zdarzeń przestrzennych. Zarówno ludzie jak i przedmioty odznaczają się 'cielesnością', dzięki której mogą różnicować przestrzeń i tworzyć określone pola ${ }^{12}$.

Mówca w Hyde Parku tworzy wokót siebie pole, w którym gromadzą się jego słuchacze. Dzieci w przedszkolu siedząc na podłodze w kręgu tworzą pole zabaw etc. (II. 10) Wykorzystując pojęcie pola opisujemy zachowania człowieka w środowisku. Człowiek albo pozostaje w pewnym polu, albo przemieszcza się. Pozostawanie człowieka w polu oznacza, że jest on określony potencjałem pola. To gdzie jest, określa w pewnym sensie kim jest i co może zrobić.

Człowiek wchodzący do sklepu staje się klientem i jego czynności z reguły ograniczają się do zrobienia zakupów. W normalnych okolicznościach nie rozegramy meczu pitkarskiego w sklepie, ponieważ nie pozwala na to zarówno wielkość pomieszczenia lukład przedmiotów wyodrębniających pole - w tym wypadku przegród bu-
In this case, fields containing other fields are created at the same time. The 'classic' process is shortened and simplified-one entity performing the transformation is responsible for several levels of organisation.

The construction of a modern residential building is a multi-level transformation. Within the plot (level $n$ field) there is a building (level $n+1$ field), in which there are residential premises (level $n+2$ fields) and in them-generally-separate rooms (level $n+3$ fields).

\subsection{The self-organisation of the field}

Self-organisation is a special type of process. Its essence is the emergence of a higher order structure through mutual interactions of lower order elements (a so-called emergent phenomenon). Self-organisation is a bottom-up process: the global field does not exist previously in whole, but 'emerges' along with individual local fields.

Self-organisation does not contradict the principle of episodic events and field durability, since field durability includes all transformations, but its shape changes with transformations (il. 8).

One example of self-organisation of a built environment is 'spontaneous' urbanisation. Bill Hillier described the process based on simple rules for grouping individual buildings and open spaces accompanying them (il. 9). Along with the construction 

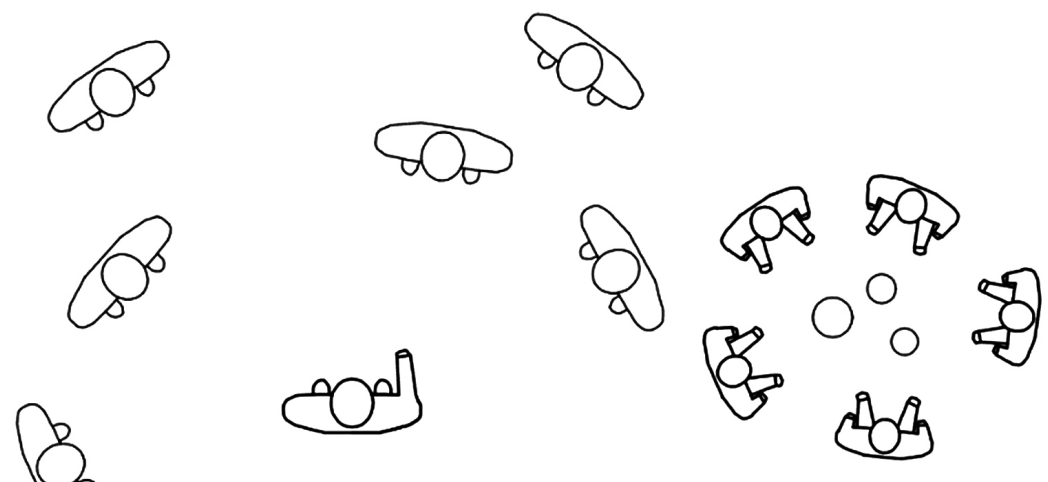

\section{a}

dowlanych), jak i zasady zachowania w sklepie (kontrola sprawowana przez personel sklepu).

Przemieszczenie oznacza z reguły ruch pomiędzy polami. (II. 11) Ruch wewnątrz pola bez naruszania granic innych pól jest raczej przypadkiem szczególnym, np. tańcem, przechadzaniem się etc.

Wyjście z domu na ulice, albo wyjazd za miasto jest przemieszczeniem z pola zawieranego w obszar ogólny pola zawierającego. Zmiana stolika $w$ restauracji wymaga opuszczenia pola stolika 1, wyjścia w obszar pola zawierającego - sali restauracyjnej i wejścia w pole stolika 2.

Jednym z tradycyjnych problemów teorii architektury jest pytanie o wpływ przestrzeni na zachowanie człowieka. Czy w świetle przedstawionego modelu struktury przestrzenne mogą całkowicie determinować ludzkie aktywności ?

Bezpośredni związek przyczynowy określonej formy przestrzennej i ludzkiego zachowania (ścisły determinizm) jest trudny do wykazania. Można mówić o wpływie pola na określone zachowania, przy czym występują tu dwa odrębne czynniki: ukształtowanie fizyczne pola oraz kontrola społeczna tego pola. Pierwszy czynnik określa afordancje, czyli możliwości dla ruchu i aktywności fizycznej dla danej

II. 11 Przemieszczanie się człowieka w środowisku jako zmiana pól (opr. własne) / Human movement in the environment as a change of fields (author's drawing)

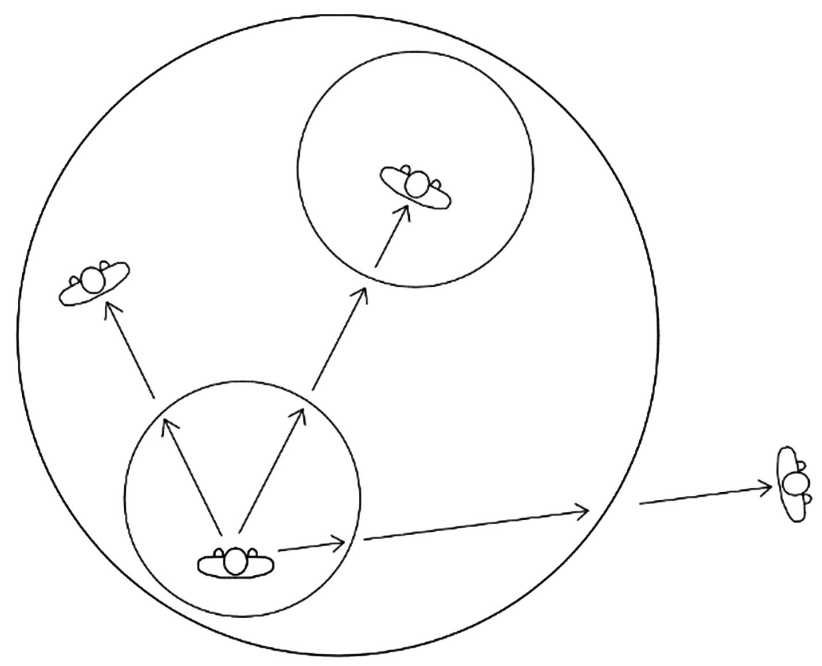

II. 10. Pola w przestrzeni tworzone przez ludzi b (opr. własne) / Fields in space created by people (author's drawing) of further houses, subsequent street sections are created (Hillier, 1984, pp. 52-62). ${ }^{9}$

\subsection{The individual in the environment}

In the traditional approach, the environment is presented as an object that exists independently of the individual and is-secondarily, in a way-experienced by said individual. ${ }^{10}$ However, the individual is not only the recipient of the environment (or even the recipient and creator at the same time) but also its integral part. (Hillier, 1984, pp. 3-9).

The built environment consists of people and physical objects. Both categories are observable facts and both fall into the broader category of spatial events. Both people and objects are characterised by 'corporeality', thanks to which they can differentiate space and create specific fields. ${ }^{11}$

The speaker at Hyde Park creates a field around him in which his listeners gather (il.10a). Children in a kindergarten, sitting on the floor in a circle, create a playground etc. (il. 10b)

Using the concept of the field, we can describe human behaviour in the environment. Humans either stay in a certain field or move. The act of staying of the person in the field means that he or she is determined by the potential of the field. That place of his/her presence is determining in a sense whom he/she is and what he/she can do.

A person entering the store becomes a customer and their activities are usually limited to shopping. Under normal circumstances, we will not play a soccer match in a store, because both the size of the room (affordance) and the rules of behaviour do not allow it (field control). To move in the environment usually means to move between fields (il. 11). The movement inside the field without disturbing the boundaries of other fields is rather a special case-e.g. dancing, walking 'up and down' etc. Going out of the house into the street or leaving the city is a movement from a field contained in the general area of a containing field. Changing a table in the restaurant requires leaving the table 1 field, going out into the containing field - the restaurant hall, and entering the table 2 field. 
osoby (różne dla różnych osób), drugi zaś narzuca określone wzorce zachowań, oraz formalne i nieformalne reguły. Ograniczenia przestrzeni fizycznej mogą być pokonane większym wydatkiem energetycznym, a reguły społeczne złamane (np. przejście przez płot), jednak prawdopodobieństwo takich zachowań jest niskie. Związek określonych pól i zachowań ma charakter probabilistyczny.

Rozwój technologii komunikacyjnych (ICT) pozwala na częściowe przekroczenie ograniczeń materialnego środowiska i przeniesienie do cyberprzestrzeni wielu sfer życia, które były dotychczas ściśle uwarunkowane przestrzennie. Jak mówi Christian Portzamparc "Przestrzeń nie jest już tym samym, ponieważ przestała być naszym jedynym medium. (...) Mając niematerialne środki komunikacji, ludzie żyją w dychotomii, lub nawet w rozdarciu pomiędzy materialną i niematerialną przestrzenią" (Portzamparc, 2020).

\section{Architektura jako część procesu organizacji środowiska}

Jak pokazano w części 2, habitat jest rodzajem meta-procesu, w którym jednostki, grupy i instytucje społeczne przekształcają środowisko w rożnych skalach przestrzennych i czasowych. Architektura jest istotnym komponentem tego procesu. Zgodnie z przedstawionym modelem, możemy opisać architekturę jako podproces, w którym powstają elementy środowiska (np. zespoły budynków, budynki, pomieszczenia, wyposażenie itp.) i który spełnia dodatkowo określone warunki ${ }^{13}$. Architektura powstaje $\mathrm{w}$ świadomym procesie twórczym ${ }^{14}$. Nie jest zatem bezrefleksyjnym powtarzaniem istniejącego wzorca, wynikającego z tradycji lub utartej praktyki. Podstawą procesu projektowania jest krytyczna analiza wzorców i ich przetworzenie w nowej syntezie. Architekturze towarzyszy świadoma intencja kreowania nowości (Hillier, 2004 s. 10-38). Kolejną istotną cechą architektury jest jej status jako sztuki, przez co należy rozumieć intencję przekroczenia czystej użytkowości i poszukiwanie wartości estetycznych. Wreszcie: profesjonalny charakter, czyli poparcie procesu projektowego ponadprzeciętną wiedzą i umiejętnościami. Wiedza polega na szerokiej znajomości wzorców, umiejętności zaś mają charakter kombinatoryjny, pozwalając na konfigurowanie wzorców w nowych zestawieniach. Wiąże się to nieodłącznie ze stworzeniem środowiska zawodowego i systemu nauczania architektury.

Te trzy cechy łącznie - świadomy proces twórczy, intencja estetyczna, oraz profesjonalizacja procesu projektowania - wyróżniają architekturę (a także dziedziny pokrewne - urbanistykę, architekturę krajobrazu etc.) na tle całości procesu organizacji przestrzeni ${ }^{15}$.

Z perspektywy historycznej, udział architektury i architektów w procesie organizacji środowiska zmieniał się. Jak zauważa Habraken, u początków nowożytnej profesji architektonicznej udział ten ograniczał się do budynków reprezentacyjnych. Tzw. środowisko codzienne powstawało bez angażowania wysoko kwalifikowanych specjalistów. Istniał zatem wyraźny rozdział domeny architektonicznej od wernakularnej (Habraken, 2005, s. 1-29).
The relation of space and human behaviour is a traditional problem of architectural theory. Can spatial structures completely determine human activities? The direct causal relationship between a specific spatial form and human behaviour (strict determinism) is difficult to demonstrate. One can speak of the impact of the field on specific behaviours, but there are two separate factors: the physical shape and social control of the field. The first factor defines affordances, that is, the possibilities for movement and physical activity (different for different people), while the second imposes specific behaviour patterns, as well as formal and informal rules. Restrictions on physical space can be overcome by greater energy expenditure and social rules can be broken (e.g. crossing a fence), but in a stable society the probability of such behaviour is lower than adhering to those limitations. Therefore, the relationship between specific fields and human behaviours is probabilistic rather than deterministic. ${ }^{12}$

The development of communication technologies (ICT) allows for partial exceeding the limitations of the material environment. Many spheres of life that were previously strictly spatially conditioned are now transferred to cyberspace. As Christian Portzamparc said: 'Space is no longer the same because it is no longer our only medium. (...) With immaterial forms of communication, people are living a dichotomy, a rift even, between material and immaterial space.' (Portzamparc, 2020)

\section{Architecture as a component of the organisation process}

As outlined above, the habitat is a kind of meta-process in which individuals, groups and social institutions transform the environment at various spatial and temporal scales. Architecture is an important component of this process. According to the presented model, we can describe architecture as a sub-process in which elements of the environment are created (e.g. building assemblies, buildings, rooms, equipment, etc.) and which additionally meets certain conditions. ${ }^{13}$ Architecture is created in a conscious creative process. ${ }^{14}$ Therefore, it is not a thoughtless repetition of an existing pattern resulting from tradition or common practice. The basis of the design process is critical analysis of patterns and their processing in a new synthesis. Architecture is accompanied by a conscious intention to create novelty (Hillier, 2004 pp. 10-38). Another important feature of architecture is its status as art, which should be understood as the intention to transcend pure utility and search for aesthetic values. Finally: professional character, i.e. supporting the design process with knowledge and skills. Knowledge is based on broad familiarity with patterns, while skills are combinatorial, allowing to configure patterns into new combinations. This results in creating a professional system of knowledge transfer, i.e. faculties of architecture, architectural criticism, professional literature, professional bodies etc.

Together, these three features-the conscious creative process, aesthetic intention, and professionalisation of 
Początek XX wieku przyniósł przełom: w kompetencji architektów znalazły się dzielnice mieszkalne, domy i miejsca pracy. Współcześnie, zwłaszcza w krajach rozwiniętych, obecność architekta w przekształcaniu środowiska wydaje się być oczywista i coraz bardziej widoczna.

Aktualna jest zatem refleksja nad zależnością architektury od metaprocesu. Przede wszystkim, architektura, tak jak każda inna transformacja przestrzenna, ma na celu tworzenie nowych pól i zdarzeń. Podobnie jak każde inne zdarzenie w przestrzeni jest uwarunkowana potencjałem pola i kontrolą społeczną, wykorzystując przy tym istniejące wzorce przestrzenne.

Tak więc, architektura nie jest autonomiczna, ale zawsze wewnętrznie i zewnętrznie powiązana z szerszą całością przestrzenną oraz kontekstem społecznym. Ten aspekt wydaje się być zaniedbywany w teorii i krytyce architektonicznej.

Przyczyną tego stanu rzeczy może być fakt, że projektowanie architektoniczne, bardziej niż inne rodzaje transformacji środowiska, opiera się na abstrakcyjnych modelach. Wykwalifikowany architekt z dużą biegłością posługuje się myślowymi konstruktami, które są następnie aktualizowane w czasie i przestrzeni w formie rzeczywistych domów i miast. Tego rodzaju abstrakcja i uproszczenie są niezbędne do przekształcania złożonego środowiska. Błędem jest jednak utożsamianie modelu i rzeczywistości ${ }^{16}$.

Jak zauważa Habraken, myślenie o architekturze w kategoriach wyizolowanych obrazów stało się częścią ekskluzywnej zawodowej ideologii architektów, mającej korzenie w renesansowych teoriach (Habraken, 2005, s.31-53). Zgodnie z tą ideologią, istotą pracy architekta jest wytworzenie skończonego i statycznie pojmowanego obiektu. Związki dzieła architektonicznego z otoczeniem ${ }^{17}$, oraz jego rzeczywistość wewnętrzna - np. partycypacja użytkowników we współorganizowaniu przestrzeni - są bagatelizowane.

Postawę tę - wyznaczającą wciąż standardy krytyki i dydaktyki architektonicznej - nazwać można paradygmatem obiektu.

Jeżeli weźmiemy pod uwagę współczesny postulat zrównoważonego rozwoju lub dominujące w naukach tzw. myślenie systemowe, paradygmat obiektu w architekturze wydaje się być trudny do utrzymania.

Przedstawiony model organizacji środowiska skłania do zastąpienia dotychczasowego paradygmatu nowym paradygmatem pola. W myśl tej idei, struktura przestrzenna nie jest samodzielna, ale stanowi integralną częścią pola, w którym się aktualizuje. Używając metafory filozofa Gillesa Deleuze'a jest „sfałdowaniem” większej całości, które następnie samo może zostać „sfałdowane"18. Przyjęcie tego paradygmatu zmienia kryteria wartościowania architektury. Dzieło architektoniczne traci wartość autonomiczną, na pierwszy plan wysuwa się problem wzmocnienia integralności pola, oraz zapewnienie warunków dla nowych zdarzeń i transformacji.

Paradygmat pola sytuuje architekta jako uczestnika szerszego procesu organizacji przestrzeni i akcentuje kwestię jego współpracy z pozostałymi uczestnikami - w tym z innymi projektantami oraz bezpośrednimi użytkowni- the design-distinguish architecture from the entire process of space organisation. ${ }^{15}$

In a historical perspective, the participation of architecture and architects in the organising the environment has changed. As Habraken noted, at the beginning of the modern architectural profession it had been limited to formal buildings. The so-called 'everyday environment' was emerging without the involvement of highly qualified specialists. Therefore, a clear delimitation of the architectural and vernacular domains was possible (Habraken, 2005, pp. 1-29). The breakthrough came with twentieth century, when professional architects started designing residential districts, houses and workplaces. At present, especially in developed countries, the presence of an architect in transforming the everyday environment seems to be obvious and increasingly visible. Therefore, the dependence of architecture on the meta-process is an inevitable problem.

Firstly, architecture, like any other spatial transformation, aims to create new fields and events. Like any other spatial event, it is conditioned by the field's potential and social control, using existing spatial patterns. So-architecture is not autonomous, but always internally and externally connected with the greater spatial whole and social context. This aspect seems to be underestimated in architectural theory and criticism. The reason for this may be the fact that architectural design, more than other types of environmental transformation, is based on abstract spatial models. A qualified architect with great proficiency uses mental constructs, which are then updated in time and space in the form of real houses and cities. Such abstraction and simplification are necessary to transform a complex environment. However, it is a mistake to identify the model and reality. ${ }^{16}$

As Habraken noted, thinking about architecture in terms of isolated images has become part of the exclusive professional ideology of architects, which has its roots in the ideas of the Renaissance (Habraken, 2005, pp. 31-53). Accordingly, the essence of the architect's work is to create a finite and statically conceived object. The relationship between an architectural work and its surroundings is underestimated, ${ }^{17}$ as well as its internal reality-e.g. user participation in the co-organisation of space.

The attitude - still setting the standards of architectural criticism and education - can be called the paradigm of the object. If we consider the contemporary postulate of sustainable development or the so-called system thinking, the current paradigm in architecture seems to be difficult to preserve.

The discussed theories are leading to replace the current paradigm with the paradigm of the field. According to this idea, a spatial structure is not independent, but is an integral part of its surroundings. Using the metaphor of the philosopher Gilles Deleuze, it is 'a folding' of a larger whole, which then can itself be 'folded' internally. ${ }^{18}$ Adopting this paradigm changes the criteria for valuing architecture. The architectural work loses its autonomous value. The problem of 
kami. I tak, architektura nie jest już sztuką wytwarzania pojedynczych obiektów, ale kolektywnym procesem twórczym, którego efektem są bardziej spójne całości przestrzenne. Architekt przestaje pełnić rolę niezależnego kreatora, stając się ekspertem wspomagającym społeczeństwo w kolektywnym procesie twórczym. Wyzwaniem dla architekta jest prawidłowe rozpoznanie zakresu interwencji i pozostawienie maksymalnej swobody innym uczestnikom procesu. Kluczowa jest świadomość działania w określonym polu i fakt, że każda interwencja ma rolę służebną wobec zdarzeń, które może wygenerować. Akcentowana jest także ciągłość, potrzeba starannej analizy lokalnych uwarunkowań, typologii, wzorców i wartości kulturowych, czerpanie z tradycji wernakularnej i budownictwa nie będącego stricte architekturą. Wszystko to nie oznacza bynajmniej deprecjacji zawodu architekta, ale jego włączenie do procesu organizacji środowiska na naturalnych dla tego środowiska zasadach.

\section{Podsumowanie}

W proponowanym ujęciu habitat jest pulsującym organizmem, czerpiącym energię z kreatywności, a równocześnie systemem organizacji zdarzeń tj. wzajemnych interakcji pomiędzy ludźmi oraz ludźmi i przedmiotami. Zdarzenia te zachodzą w obrębie względnie statycznych uporządkowań (tj. w polach), a ich zmiana następuje poprzez przemieszczanie się ludzi i przemieszczanie przedmiotów. Do organizacji środowiska należy stworzenie potencjału zdarzeń oraz ich realizacja, otwierająca nowe potencjały.

Osobną część poświęcono roli, jaką może mieć do spełnienia projektowanie architektoniczne jako część tak pojętego procesu. W związku z tym, postuluje się zastąpienie dotychczasowego paradygmatu obiektu paradygmatem pola.

W ramach dalszych badań przedstawione hipotezy poparte będą analizą konkretnych przykładów studialnych zaczerpniętych ze współczesnego środowiska miejskiego. Potrzebne jest również rozwinięcie niektórych aspektów pracy, obejmujących zwłaszcza:

1/ perspektywę historyczną pozwalającą na prześledzenie ewolucji środowiska zbudowanego oraz zmieniającej się roli architektury.

2/ konsekwencje estetyczne przyjętych założeń i kryteria ewaluacji estetycznej architektury

3/ współczesne instrumentarium projektowe ułatwiające kolektywny proces organizacji przestrzeni i współpracę pomiędzy poszczególnymi jego uczestnikami, oraz jego wpływ na praktykę architektoniczną.

Zastosowania praktycznego przedstawionych badań szukać należy przede wszystkim w dziedzinach kształtujących świadomość społeczną na temat architektury - zarówno w wydaniu profesjonalnym jak i popularnym - tj. w krytyce oraz w dydaktyce architektonicznej. Upowszechnienie całościowego i procesualnego myślenia o środowisku może wydatnie przyczynić się do wzrostu poczucia odpowiedzialności za jakość habitatu. strengthening the integrity of the field and providing conditions for new events comes to the fore.

The field paradigm situates the architect as a participant in the broader process of space organisation. It emphasises the issue of the architect's cooperation with other process participants-including other designers and direct users. Architecture is no longer the art of producing objects. It can be understood as a collective creative process that results in consistent spatial entities. An architect stops being an independent creator, becoming an expert supporting society in a collective creative process. Every intervention is subordinated to the events it can generate. The challenge for an architect is to limit the scope of design and leave maximum freedom to other participants in the process. The crucial factors here are continuity, careful analysis of local conditions, typology, cultural patterns and values, exploring vernacular tradition and non-architectural construction. All this does not mean a depreciation of the architectural profession, but its inclusion in the process of organising the environment on its natural terms.

\section{Conclusions}

In the proposed approach, the habitat is a pulsating organism, drawing energy from creativity, and a system of organised events, i.e. mutual interactions between people, as well as people and objects. These events occur within relatively static arrangements (i.e. in fields), and their change occurs through the movement of people and the movement of objects. The organisation of the environment is to create the potential of events and their implementation that is opening new potentials. The role of architectural design as part of this process was also briefly discussed. A new kind of paradigm was proposed, which postulates placing emphasis on the field instead of the object.

The following aspects of the discussed theories need to be developed in the future research:

1) a historical perspective of the evolution of the built environment and the changing role of architecture,

2) aesthetic consequences of the discussed theories and possible methods of aesthetic assessment of architecture,

3) contemporary design tools that may facilitate the collective process of space organisation and cooperation between its individual participants, as well as its impact on architectural design.

The presented hypotheses need to be supported by the case studies taken from the contemporary urban environment and architectural practice.

The practical applications of the current research are to be found primarily in the areas shaping public architectural awareness - both in the professional and popular sense-i.e. in criticism and architectural education. The dissemination of holistic and processual thinking about the environment can significantly contribute to an increase in the sense of responsibility for the quality of the habitat. 


\section{PRZYPISY}

${ }^{1}$ Terminy habitat i środowisko zbudowane stosowane są zamiennie. Szersze omówienie pojęcia habitatu autor przedstawił w pracy "Habitat as a research model: relations, territory, proces" (Januszewski, 2019).

2 Podejście strukturalistyczne $\mathrm{w}$ teorii architektury ma źródło $\mathrm{w}$ poszukiwaniach powojennej awangardy, zwłaszcza Petera i Alison Smithsonów, Jacoba Bakemy i Aldo van Eycka. Wśród późniejszych ujęć wymienić należy teorię wzorców Christophera Alexandra (Alexander, 1977), a także teorię Space Syntax Billa Hilliera (Hillier 1984)

${ }^{3}$ Np. miasto - dzielnica - blok zabudowy - budynek - pomieszczenie - umeblowanie. Poszczególne środowiska moga cechować się odmiennym układem poziomów (Habraken, 2000, s. 22-24).

${ }^{4}$ Fragmenty tekstu wyodrębnione kursywą.

5 Pojęcie pola nie jest nowościa w teorii architektury. Norberg-Schulz pisze: „W przestrzeni architektonicznej, tak samo jak w egzystencjalnej, miejsce, droga i strefa tworzą zintegrowaną całość, co można by nazwać polem" (Norberg-Schulz, 2000, s. 59). Również Habraken często używa pojęcia pola, zwłaszcza w odniesieniu do skali urbanistycznej (Habraken, 2005, s. 55-82)].

${ }^{6}$ Pokrewnym pojęciem jest afordancja oznaczająca możliwości działania jakie stwarza środowisko. Afordancje wynikają z konfiguracji przedmiotów, podczas gdy potencjał uwzglednia również szereg norm społecznych. Potencjał jest zatem sumą afordancji i kontroli. Zob. (Gibson, 1986, s.127-143) i (Lenartowicz, 1997, s.8)

7 Problem rdzenia był przedmiotem teoretycznych poszukiwań powojennego CIAM i Team 10. (Marchi, 2018, s. 72-108) Dyskusja na ten temat doprowadziła do rewizji założeń klasycznego modernizmu i wypracowania współczesnych kategorii myślenia o mieście. Innym ważnym pojęciem z tego okresu jest przestrzeń progowa. Zob. (Van Eyck, 1968)

8 Antynomia przestrzeni negatywowej i pozytywowej (Alexander, 1977. pp. 525-531) była ważnym przedmiotem debaty w II poł. XX wieku. Siegfried Giedion pisał o dwoistości przestrzeni wydrążonej i przestrzeni emanującej z bryły (Giedion, 1968, s.15-19), a Colin Rowe o modelu „Akropolu" i .Forum" (Rowe, Koetter, 1980).

${ }^{9}$ Wzorzec jest odpowiednikiem przedmiotu wiecznego z filozofii Whiteheada, natomiast pole i zdarzenie odpowiadają kategorii zaistnienia aktualnego. 'Wieczność' polega na bezczasowości, a 'aktualność' oznacza istnienie w czasie i przestrzeni (Cobb, 2016, s. 52-59).

10 Podobne procesy zachodzą w skali metropolitalnej. Przestrzeń miejska może być rozumiana jako samoorganizujące się pola, które wzrastaja wraz z namnażaniem pól lokalnych (terenów inwestycyjnych) poprzez dodawanie i łączenie nowych fragmentów sieci komunikacyjnej. Oczywiście samoorganizacja rzadko występuje w stanie 'czystym', a odgórne i oddolne procesy w różnych skalach współuczestniczą w tworzeniu miast.

11 Doktrynę tę można nazwać za Rapoportem „paradygmatem człowiek-środowisko". W nurcie tym badany jest wpływ środowiska na zachowania, emocje, tworzenie obrazów myślowych tego środowiska, nadawanie mu znaczeń etc. (Rapoport, 1977, pp. 1-7).

12 Problemem pól wytwarzanych przez ludzi zajął się E.T Hall w klasycznej pracy "Ukryty wymiar" (Hall, 1976).

${ }^{13}$ Probabilistyczna teoria konfiguracji przestrzennych została przedstawiona przez Hilliera w pracy "Space is the machine"(Hillier, 2004).

${ }^{14}$ Można spotkać się z opinią, że każdy budynek powinien być traktowany jako architektura, ponieważ finalnie niesie wartość estetyczna, oraz przekaz znaczeniowy (Scruton, 1979, s. 23-25). Ta definicja pomija jednak charakter procesu, w którym powstaje budynek.

${ }^{15}$ Rozróżnienie procesu świadomego typowego dla współczesnego projektowania i nieświadomego, którym kierowały się społeczności tradycyjne wprowadzit Christopher Alexander w Notes on the Synthesis of Form. (Alexander, 1964, s.46-70)

${ }^{16}$ Niewłaściwe wydaje się proste utożsamienie architektury z pracą zawodowa architekta. Watpliwy jest status niektórych współczesnych typów budynków jako architektury sensu stricto, pomimo faktu, że formalnie sygnowane są przez architektów. Dotyczy to np. obiektów powtarzalnych, typowych, lub takich w których aspekt techniczno-ekonomiczny całkowicie dominuje nad aspektem twórczym. Niemniej jednak można przyjać, że sednem pracy architekta jest świadoma kreacja o intencjach estetycznych, poparta wiedzą fachową.

17 Jak pokazał w znakomitym studium Stewart Brand, wzniesione budynki z czasem przestaja odpowiadać pierwotnej wizji, 'żyja własnym życiem', podlegają przekształceniom i adaptacjom. (Brand, 1994 s.14-30).

18 Patrz niesławne hasło "Fuck context" R. Koolhaasa.

19 Według Deleuze'a : „Zewnętrze nie jest ustaloną granica, ale płynną materia ożywiona ruchami perystaltycznymi, fałdami, które razem tworza wnętrze, nie są one czymś innym niż zewnętrze, są dokładnie wnętrzem zewnętrza." (Deleuze, 2006, s. 80)

\section{LITERATURA}

[1] Alexander, C., Ishikawa, S., Silverstein, M., A Pattern Language, Oxford University Press, New York 1977.

[2] Alexander Ch., Notes on the synthesis of form, Harvard University Press, Cambridge MA 1964

\section{ENDNOTES}

The terms habitat and built environment are used interchangeably. The author presents the broader description of the habitat concept in his work 'Habitat as a research model: relations, territory, process' (Januszewski, 2019)

2 The structuralist approach in architectural theory has its source in post-war avant-garde, especially Peter and Alison Smithson, Jacob Bakema, and Aldo van Eyck. The theory of patterns by Ch. Alexander (Alexander, 1977), as well as the theory of 'spatial syntax' by Bill Hillier (Hillier 1984), should be mentioned among the later theories. ${ }^{3}$ E.g. city-district-building block - building - room - furniture. Each specific environment has a separate hierarchy, but the very fact that such a hierarchy is present is universal (Habraken, 2000, pp. 22-24). 4 The concept of field is not new to architectural theory. NorbergSchulz writes: 'In architectural space, as in the existential one, the place, road, and zone form an integrated whole which could be called a field' (Norberg-Schulz, 2000 p. 59). Habraken also willingly uses the concept of the field, especially in relation to the urban scale (Habraken, 2005, s. 55-82).

${ }^{5} \mathrm{~A}$ related term is affordance, which means the opportunities for action given by the environment. Affordances result from the configuration of objects, while the field potential also includes a number of social norms. Potential is therefore the sum of affordances and control. (Gibson, 1986, pp.127-143), (Lenartowicz, 1997, p.8). ${ }^{6}$ The issue of the core was the subject of the theoretical search of the post-war CIAM and Team 10. (Marchi, 2018, pp. 72-108) The discussion on this topic led to the revision of many assumptions of classical modernism and the development of contemporary categories of thinking about the city, e.g. about the so-called public space. The threshold space is also an important concept from this period (Van Eyck, 1968).

The antinomy of negative and positive spaces (Alexander, 1977 pp. 525-531) was an important subject of a debate in the second half of the 20th century. Siegfried Giedion wrote about the duality of hollow space and space emanating from a solid (Giedion, 1968 pp.15-19), while Colin Rowe - about the model of the 'Acropolis' and 'Forum' (Rowe, Koetter, 1980).

8 The pattern is equivalent to the eternal object of Whitehead's philosophy. The field and event, on the other hand, correspond to the category of actual occasion. 'Eternity' consists precisely of timelessness, while 'actuality' means the existence in time and space (Cobb, 2016, pp. 52-59).

9 Similar processes occur on a metropolitan scale. Urban space can be understood as self-organising fields that grow with the multiplication of local fields (investment areas) by adding and connecting new fragments of the global communication network. Certainly, self-organisation rarely occurs in the 'pure' state, and both top-down and bottom-up processes participate in the creation of cities at various scales.

10 This doctrine can be called after Rapoport a 'human-environment paradigm'. This trend examines the impact of the environment on behaviour, emotions, creating mental images of that environment, giving it meanings, etc. (Rapoport, 1977, pp. 1-7).

1 The aspect of human-made fields are ,distances' discussed by E.T. Hall in the classic work ,Hidden Dimension' (Hall, 1976).

12 The probabilistic theory of spatial configuration was presented by Hilier in "Space is the machine"(Hillier, 2004).

${ }^{13} \mathrm{~A}$ popular theory states that every building should be treated as architecture, because finally each of them carries an aesthetic value and a meaning (Scruton, 1979, pp. 23-25). This definition, however overlooks the nature of the process in which the building is created. 14 The distinction between the conscious process of contemporary design and the unconscious which guided traditional communities was introduced by Ch. Alexander in Notes on the Synthesis of Form. (Alexander, 1964, pp.46-70)

${ }^{15}$ It seems incorrect to simply identify architecture with the architect's work. The status of certain types of buildings as architecture in the strict sense is doubtful, despite the fact that they are formally signed by architects. This applies, for example, to repetitive and typical buildings, or objects in which the technical and economic aspect completely dominates the creative aspect. Nevertheless, it can be assumed that the essence of the architect's work is a conscious creation with aesthetic intentions, supported by professional knowledge. ${ }^{16}$ As an excellent Stewart Brand's study showed, buildings erected 'live their own lives' (Brand, 1994 pp.14-30)

17 Symbolized by infamous "fuck context" slogan by R. Koolhaas. 18 "The outside is not a fixed limit but a moving matter animated by peristaltic movements, folds and foldings that together make up an inside: they are not something other than the outside, but precisely the inside of the outside." (Deleuze, 2006, p. 80)

\section{REFERENCES}

[1] Alexander, C., Ishikawa, S., Silverstein, M., A Pattern Language, Oxford University Press, New York 1977. 
3] Baranowski A. Dylematy paradygmatu architektury, [w:] Gzell S. (red.), Architektura, urbanistyka, nauka, PWN, Warszawa 2019, s.217225

[4] Brand S., How buildings learn. What happens after they're built Penguin Books, New York 1994.

[5] Cobb J., Słownik pojeć Whiteheada, Copernicus Center Press, Kraków 2016.

[6] Deleuze G,. Foucault, Bloomsbury Academic, London 2006.

[7] Gibson J.J., The Ecological Approach to Visual Perception. Psychology Press, New York 1986

[8] Giedion S., Przestrzeń, czas i architektura. Narodziny nowej tradycji. PWN, Warszawa 1968

[9] Habraken N., J., Aap Noot Mies Huis. Three r's for housing, "Forum" 1966, No. 1, s. 138.

[10] Habraken N., J., Palladio's Children, Taylor\&Francis, New York 2005.

[11] Habraken N., J., The Structure of the Ordinary: Form and Control in the Built Environment, The MIT Press, Cambridge, Mass. 2000.

[12] Hall E., T., Ukryty wymiar, PIW, Warszawa 1976

[13] Hillier B., Space is the Machine, Space Syntax, London 2004.

[14] Hillier, B. and Hanson, J., The social logic of space, Cambridge University Press, Cambridge 1984.

15] Januszewski W., Habitat as a research model: relations, territory, process, [w:] Bać Z. (red.), Teoria habitatu. Wspótczesny kontekst, Oficyna Wydawnicza Politechniki Wrocławskiej, Wrocław 2019, s. 91-101. [16] Lenartowicz K., Stownik psychologii architektury dla studiujących architekture, Politechnika Krakowska, Kraków 1997.

[17] Marchi L.Z., The Heart of the City. Legacy and Complexity of

a Modern Design Idea, Routledge, New York 2018.

[18] NorbergSchulz Ch., Bycie, przestrzeń i architektura, Architektura-Murator, Warszawa 2000.

[19] Piaget J., Strukturalizm, Wiedza Powszechna, Warszawa 1972

[20] Portzamparc Ch., The new age of the city, www.pca-stream. com/en/articles/the-challenges-of-urban-despatialization-30 [dostęp 20.06.2020]

[21] Rapoport, A., Human Aspects of Urban Form, Pergamon, Oxford 1977.

[22] Rowe C., Koetter C., Crisis of the Object. Predicament of Texture, "Perspecta", Vol. 16 (1980), s. 108-141.

[23] Scruton, R., Aesthetics of Architecture, Methuen \& Co., London 1979.

24] Van Eyck, A., Doorstep, [w:] Smithson, A. (red.) Team 10 Primer, Studio Vista, London 1968, s.96.

[25] Whitehead A.N., Process and Reality. Corrected Edition, The Free Press, London 1978
[2]Alexander Ch., Notes on the synthesis of form, Harvard University Press, Cambridge MA 1964

[3] Baranowski A. Dylematy paradygmatu architektury , [in:] Gzell S. (ed.), Architektura, urbanistyka, nauka, PWN, Warszawa 2019, p. 217-225.

[4] Brand S., How buildings learn. What happens after they're built, Penguin Books, New York 1994.

[5] Cobb J., Słownik pojęć Whiteheada, Copernicus Center Press, Kraków 2016.

[6] Deleuze G.. Foucault, Bloomsbury Academic, London 2006.

[7] Gibson J.J., The Ecological Approach to Visual Perception, Psychology Press, New York 1986.

[8] Giedion S., Przestrzeń, czas i architektura. Narodziny nowej tradycji, PWN, Warszawa 1968

[9] Habraken N., J., Aap Noot Mies Huis. Three r's for housing, "Forum" 1966, No. 1, p. 1-38.

[10] Habraken N., J., Palladio's Children, Taylor \& Francis, New York 2005

[11] Habraken N., J., The Structure of the Ordinary: Form and Control in

the Built Environment, The MIT Press, Cambridge, Mass. 2000.

[12] Hall E., T., Ukryty wymiar, PIW, Warszawa 1976.

[13] Hillier B.. Space is the Machine, Space Syntax, London 2004

[14] Hillier, B. and Hanson, J., The social logic of space, Cambridge University Press, Cambridge 1984.

[15] Januszewski W., Habitat as a research model: relations, territory, process, [in:] Bać Z. (ed.). Teoria habitatu. Wspótczesny kontekst, Oficyna Wydawnicza Politechniki Wrocławskiej, Wrocław 2019, p. 91-101.

[16] Lenartowicz K., Słownik psychologii architektury dla studiujących architekture, Politechnika Krakowska, Kraków 1997.

[17] Marchi L.Z., The Heart of the City. Legacy and Complexity of a Modern Design Idea, Routledge, New York 2018.

[18] NorbergSchulz Ch., Bycie, przestrzeń i architektura, Architektura-Murator, Warszawa 2000.

[19] Piaget J., Strukturalizm, Wiedza Powszechna, Warszawa 1972.

[20] Portzamparc Ch., The new age of the city, www.pca-stream.com/ en/articles/the-challenges-of-urban-despatialization-30 [accessed: 20.06.2020]

[21] Rapoport, A., Human Aspects of Urban Form, Pergamon, Oxford 1977.

[22] Rowe C., Koetter C., Crisis of the Object. Predicament of Texture, "Perspecta", Vol. 16 (1980), p. 108-141.

[23] Scruton, R., Aesthetics of Architecture, Methuen \& Co., London 1979.

[24] Van Eyck, A., Doorstep, [w:] Smithson, A. (red.) Team 10 Primer, Studio Vista, London 1968, p. 96.

[25] Whitehead A.N., Process and Reality. Corrected Edition, The Free Press, London 1978. 